\title{
Characterization of Renal Inflammatory Cytokines and Related Nephropathy in Experimentally Infected Broiler Chickens with Velogenic Newcastle Disease Virus
}

\author{
Mohamed R. Mousa ${ }^{1}$, Faten F. Mohammed ${ }^{1}$, Fatma Amer Abdel reheem ${ }^{2}$, Ayman H. El-deeb ${ }^{3}$ and Kawkab A. Ahmed ${ }^{1 *}$ \\ ${ }^{1}$ Department of Pathology, Faculty of Veterinary Medicine, Cairo University, Giza, 12211, Egypt \\ ${ }^{2}$ Reference Laboratory for Veterinary Quality Control on Poultry Production (RLQP), Animal Health Research Institute (AHRI), Giza, Egypt \\ ${ }^{3}$ Department of Virology, Faculty of Veterinary Medicine, Cairo University, Giza, 12211, Egypt \\ *Corresponding author’s Email: kawkababdelaziz@yahoo.com; ORCID: 0000-0001-7376-7411
}

Received: 03 Jan. 2020

Accepted: 15 Feb. 2020

\begin{abstract}
Velogenic Newcastle disease virus (VNDV) shows systemic dissemination and it affects the histological structure and function of the kidneys. Present study is an novel attempt to correlate the changes in renal biochemical functions and gene expression of different inflammatory cytokines with related renal pathology induced by VNDV in experimentally infected broilers in different ages. One hundred broiler chickens were divided into 4 groups: group 1 served as control (non-infected group), and groups 2,3 and 4 were inoculated with $10^{6} \mathrm{EID}_{50}$ of NDV on the $10^{\text {th }}, 20^{\text {th }}$ and $30^{\text {th }}$ days of age, respectively. Serum samples were collected to evaluate uric acid and creatinine levels. Kidney specimens were collected for virus detection using real time RT-PCR, evaluation of gene expression of IL-6 and IFN$\gamma$ as well as histopathological, histochemical and immunohictochemical analysis. The highest concentration of uric acid and creatinine profile were found in Group 4 (12.06 \pm 1.25 and $2.16 \pm 0.12$, respectively) on 7 dpi. IL-6 and IFN- $\gamma$ were significantly elevated at the $7^{\text {th }}$ dpi in Group 4 compared to other infected groups. The renal histopathological lesions included tubulointerstitial nephritis and glomerulopathy with expression of virus antigen in different areas of renal tissue. histopathology was the hallmark of VNDV infection in broiler chickens; their severity was related to the increased expression of inflammatory cytokines genes (IL- 6 and IFN- $\gamma$ ) and virus antigen residence in renal tissue.
\end{abstract}

Key words: IL-6, IFN- $\gamma$, Immunohistochemistry, Nephropathy, Velogenic NDV

\section{INTRODUCTION}

Newcastle disease (ND) is widespread disease and it affects several species of birds and causes severe losses in the poultry sector. Newcastle disease can drastically limit the amount of dietary protein and also damage the microeconomy of poultry farms (Cattoli et al., 2011; Sultan etal 2020).

Non-virulent NDVs have the typical a virulent cleavage motif, ${ }^{112} \mathrm{R} / \mathrm{G}-\mathrm{R} / \mathrm{K}-\mathrm{Q}-\mathrm{G}-\mathrm{R}^{116}$, with a leucine $\left(\mathrm{L}^{117}\right)$ at the $\mathrm{N}$ terminus of the $\mathrm{F}$ protein after cleavage (F1), which is only susceptible to trypsin-like enzymes that were limited to specific tissues such as those in respiratory and digestive tracts, causing localized infection. On the other hand, the virulent NDVs have a virulent cleavage motif, ${ }^{112} \mathrm{R} / \mathrm{K}-\mathrm{R}-\mathrm{Q}-\mathrm{R} / \mathrm{K}-\mathrm{R}^{116}$, and phenylalanine $\left(\mathrm{F}^{117}\right)$ at the $\mathrm{N}$ terminus of $\mathrm{F} 1$, which enables them to infect the host leading to systemic dissemination of virulent strains of NDV in different host tissues by acquiring susceptibility to furin or other ubiquitous intracellular host cell proteases (Nagai, 1993; De Leeuw et al., 2003). For many decades, ND has been facing problems and losses due to outbreaks of the disease despite the research and efforts made to have control and possible eradication. The wide variation of clinical signs and lesions, in addition to absence of pathognomonic clinical signs and lesions, make diagnosis very difficult (Okorie-Kanu et al., 2016).

Renal lesions induced by NDV have been reported in several avian species as in turkeys in which the presence of viral antigen was observed in a number of parenchymatous organs and not just at mucosal surfaces, reflecting systemic spread (Piacenti et al., 2006). However, few literatures were interested in renal lesions in 
NDV infections, and limited studies have addressed the relationship between histopathological alterations in chicken kidney tissues and NDV replication (El-Bahrawy et al., 2017).

Among avian species, chickens showed more susceptibility and renal histopathological alterations as previously stated in a comparative study with waterfowl which presented more prominent lesions. The pathological lesions were characterized by proliferations of the ectopic lymphoid tissues and tubulointerstitial nephritis with detection of viral nucleoprotein in degenerated renal tubules (Anis et al., 2012).

Present study aimed to investigate the gene expression of inflammatory cytokines genes and renal pathology induced by NDV infection in broiler chickens receiving no NDV vaccine during rearing, from an early to a late phase of infection and to detect the viral antigens residence in the renal tissue.

\section{MATERIALS AND METHODS}

\section{Virus}

Velogenic NDV genotype VII (NDV-B7-RLQP-CHEG-12) local strain isolated from Kafr El-Sheikh Governorate, Egypt was kindly provided by National Laboratory for Veterinary Control on Poultry Production, Animal Health Research Institute. Phylogenetically, the virus was characterized as velogenic VII which isolated by sequencing of $\mathrm{F}$ gene partially around the cleavage site and the sequence was deposited in Gen Bank with Accession Number KM288609.

\section{Infectivity titration in Embryonated chicken egg}

The NDV virus suspension was titrated on $9^{\text {th }}$ and $10^{\text {th }}$ days of inoculation. 10 fold serial dilutions of the virus in saline containing antibiotic were prepared. Virus suspension was inoculated in 5 embryos for each dilution via allantoic sac $(0.1 \mathrm{ml}$ per egg). The inoculated embryos were incubated at $37^{\circ} \mathrm{C}$ and candled twice a day for 6 days. On first day, the dead embryos were considered nonspecific deaths. Haemagglutination (HA) was applied to the allantoic fluid of inoculated chicken embryos to detect the HA-positive eggs. It was carried out according to the standard method described by Council (1971). For detection of haemagglutination in embryonic fluid, $10 \%$ of the washed chicken red blood cell suspension in saline were used. One drop of the fluid was mixed with one drop of blood suspension on glass slide and results were recorded within 2 minutes. The harvested allantoic fluid was used to determine the egg infectious dose $50\left(\mathrm{EID}_{50}\right)$ according to Reed and Muench (1938) as $10^{6} \mathrm{EID}_{50}$ to be used for infection of the chickens.

\section{Experimental design}

One hundred day old broiler chicks (Ross) were obtained from commercial poultry company. Chicks were kept in different (separated) rooms and were given water and feed ad libitum. All chicks were vaccinated against avian influenza $\mathrm{H} 5 \mathrm{~N} 1$ and infectious bursal disease virus on 10 days old and no vaccination for NDV was used. The birds were then randomly divided into four groups ( 25 per each) as follows: Control Non-infected (Group 1), infected group of 10-day old chicks (Group 2), infected group of 20-day old chicks (Group 3) and infected group of 30-day old chicks (group 4). The infected groups were inoculated intraocular with a dose $10^{6} \mathrm{EID}_{50}$ of NDV (in a total volume of $0.1 \mathrm{ml})$. Three chickens from each group were sacrificed on the $1^{\text {st }}, 3^{\text {rd }}, 5^{\text {th }}$ and $7^{\text {th }}$ days after inoculation (dpi).

\section{Serum biochemical analysis}

Serum was obtained by collecting blood samples without anticoagulant in a sterile test tube and kept for biochemical analysis. Serum uric and creatinine were determined in serum samples calorimetrically using commercial diagnostic kits (Stanbio-laboratory,USA). supplied by Spectrum Diagnostics Company and measured according to the manufacturer's instructions (Tiffany et al., 1972; Bowers and Wong, 1980).

\section{Real time RT-PCR for detection of virulent Newcastle disease \\ PCR kit (Qiagen, Inc. Valencia CA, Cat. no. 204443)} with specific primers and probes designed by Wise et al.(33) supplied from Metabion (Germany). Primers were (F+4839) 5'- TCC GGA GGA TAC AAG GGT CT-3', (F4939) 5'- AGC TGT TGC AAC CCC AAG-3' and probe was $(\mathrm{F}+4894) 5^{\prime}-$ [FAM] AAG CGT TTC TGT CTC CTT CCT CCA[TAMRA] $-3^{\prime}$.

RNA was extracted from tissue samples using RNeasy minikit (Qiagen, Germany, according to the manufacturer's recommendations). NDV specific primers were utilized in a $25 \mu \mathrm{l}$ reaction containing $12.5 \mu \mathrm{l}$ of Quantitect probe rt-PCR master mix (Qiagen, Germany, $\mathrm{GmbH}), 0.5 \mu \mathrm{l}$ of each primer of $50 \mathrm{pmol}$ concentration, $0.125 \mu 1$ of the specific probe, $4.125 \mu 1$ of RNase Free Water, $0.25 \mu \mathrm{l}$ of QuantiTect RT Mix and $7 \mu \mathrm{l}$ of RNA extract. The reaction was recorded by a Stratagene MX3005P real time PCR machine (Stratagene Co, USA). The reserve transcription step was performed at $50^{\circ} \mathrm{C}$ for 
$30 \mathrm{~min}$ followed by $15 \mathrm{~min}$ at $95^{\circ} \mathrm{C}$ as primary denaturation, while the cycle protocol was 40 cycles of three successive steps; $94^{\circ} \mathrm{C}$ for $30 \mathrm{sec}$., $52^{\circ} \mathrm{C}$ for $30 \mathrm{sec}$ and $72^{\circ} \mathrm{C}$ for $10 \mathrm{sec}$.

\section{Profiling of cytokine gene expression}

Total RNA was extracted from kidneys' tissue from infected groups at $7 \mathrm{dpi}$ using an RNeasy Mini RNA Purification Kit and RNase-Free DNase Kit (QIAGEN) for RNA purification according to the manufacturer's instructions. The expression of different cytokines was quantified by reverse transcription real-time PCR (RTPCR) using relative quantification. The primers and probes used in this study have been described previously: IL-6, IFN- $\gamma$ and 28srRNA (13) and have been described in table 1.

Quantitative real-time RT-PCR was performed using Quantitect probe RT-PCR (QIAGEN) according to the manufacturer's recommendations. Real-Time RT-PCR was carried out using a 7500 Real-time PCR System (Applied Biosystems). PCR conditions were the same for each cytokine gene, as follows: $30 \mathrm{~min}$ at $50 \mathrm{C}, 95$ _C for 15 min, followed by 40 cycles of 95 _C for 15 sand 60 _C for $1 \mathrm{~min}$.

Statistical analysis for fold changes in cytokine levels were determined by the $\Delta \Delta \mathrm{Ct}$ method (Livak and Schmittgen, 2001), using 28S ribosomal RNA as the endogenous reference gene to normalize the level of the target gene expression.
Histopathological and histochemical examination

Samples of kidneys were cut into $1 \mathrm{~cm} \times 1 \mathrm{~cm} \times 0.5$ $\mathrm{cm}$ and fixed in neutral buffered formalin $10 \%$. $5 \mu \mathrm{m}$ sections were prepared and the slides were stained with Haematoxylin and Eosin (H\&E) for histopathological examination using Olympus BX43 light microscope and captured using Olympus DP27 camera linked to Cellsens dimensions software (Olympus). Periodic acid-Schiff (PAS) and Masson's trichrome (MTC) staining were performed on selected tissue sections (Bancroft, 2013).

\section{Immunohistochemistry}

For immunohistochemistry, Paraffin blocks were collected at the $7^{\text {th }}$ dpi from different groups. NDV hyperimmune serum was prepared by series injection in rabbits (Samiullah et al., 2006). Antibody purification was performed using Magne ${ }^{\mathrm{TM}}$ Protein G Beads for Antibody Purification according to the manufacturer's instructions. Tissue sections were obtained on Poly-L-Lysine coated slides, deparaffinized and rehydrated. Antigen retrieval step was performed by heat induction and blocking of nonspecific protein binding and endogenous peroxide was followed by overnight incubation in primary antibody (Rabbit anti NDV Ig previously mentioned) then incubated with horse radish peroxidase-conjugated goat polyclonal secondary antibody to rabbit Ig (SM802 EnVision ${ }^{\mathrm{TM}}$ FLEX /HRP). Colour was developed with 3, 32 Diaminobenzidine (DAB) substrate (DM827 EnVision ${ }^{\mathrm{TM}}$ FLEX DAB+ Chromogen) (Burns et al., 2005).

Table 1. Real-time quantitative RT-PCR probes and primers

\begin{tabular}{|c|c|c|c|}
\hline \multicolumn{2}{|c|}{ RNA target } & Probe/primer sequence (5'- $\left.3^{\prime}\right)$ & Accession number \\
\hline \multirow[t]{2}{*}{$28 S$} & $\mathrm{~F}$ & GGCGAAGCCAGAGGAAACT & \multirow[t]{2}{*}{ X59733 } \\
\hline & $\mathrm{R}$ & GACGACCGATTTGCACGTC & \\
\hline \multirow[t]{2}{*}{ IL-6 } & $\mathrm{F}$ & GCTCGCCGGCTTCGA & \multirow{2}{*}{ AJ 250838} \\
\hline & $\mathrm{R}$ & GGTAGGTCTGAAAGGCGAACAG & \\
\hline IFN- $\gamma$ & Probe & (FAM)-TGGCCAAGCTCCCGATGAACGA-(TAMRA) & Y07922 \\
\hline
\end{tabular}

Table 2. Serum biochemistry profile of uric acid and creatinine of broiler chickens from different experimental groups at 1, 3, 5 and $7 \mathrm{dpi}$

\begin{tabular}{ccccccccc}
\hline \multirow{2}{*}{ Groups } & \multicolumn{4}{c}{ Uric acid (mg/dl) } & \multicolumn{3}{c}{ Creatinine (mg/dl) } \\
\cline { 2 - 8 } & $\mathbf{1 d p i}$ & $\mathbf{3 d p i}$ & $\mathbf{5 d p i}$ & $\mathbf{7 d p i}$ & $\mathbf{1 d p i}$ & 3dpi & 5dpi & 7dpi \\
\hline Group 1 & $2.63 \pm 0.28^{\mathrm{a}}$ & $2.83 \pm 0.12^{\mathrm{a}}$ & $2.66 \pm 0.17^{\mathrm{a}}$ & $2.93 \pm 0.33^{\mathrm{a}}$ & $0.14 \pm 0.01^{\mathrm{a}}$ & $0.15 \pm 0.00^{\mathrm{a}}$ & $0.16 \pm 0.03^{\mathrm{a}}$ & $0.17 \pm 0.01^{\mathrm{a}}$ \\
Group 2 & $3.33 \pm 0.16^{\mathrm{a}}$ & $4.10 \pm 0.32^{\mathrm{b}}$ & $4.16 \pm 0.44^{\mathrm{a}}$ & $4.90 \pm 0.20^{\mathrm{a}}$ & $0.70 \pm 0.05^{\mathrm{b}}$ & $1.00 \pm 0.15^{\mathrm{b}}$ & $0.80 \pm 0.05^{\mathrm{b}}$ & $1.03 \pm 0.08^{\mathrm{b}}$ \\
Group 3 & $5.16 \pm 0.38^{\mathrm{b}}$ & $5.13 \pm 0.18^{\mathrm{b}}$ & $6.83 \pm 0.60^{\mathrm{b}}$ & $7.33 \pm 0.33^{\mathrm{b}}$ & $0.76 \pm 0.08^{\mathrm{b}}$ & $1.20 \pm 0.05^{\mathrm{b}}$ & $1.63 \pm 0.17^{\mathrm{c}}$ & $1.86 \pm 0.08^{\mathrm{c}}$ \\
Group 4 & $7.73 \pm 0.73^{\mathrm{c}}$ & $8.16 \pm 0.60^{\mathrm{c}}$ & $9.33 \pm 0.72^{\mathrm{c}}$ & $12.06 \pm 1.25^{\mathrm{c}}$ & $1.26 \pm 0.06^{\mathrm{c}}$ & $1.56 \pm 0.14^{\mathrm{c}}$ & $1.90 \pm 0.05^{\mathrm{c}}$ & $2.16 \pm 0.12^{\mathrm{d}}$ \\
\hline
\end{tabular}

Values expressed as means \pm Standard Error. Different superscripts a, b and c indicate a significant different between values within the same column. Group 1 (control uninfected group), Group 2 (infected at 10 days old), Group 3 (infected at 20 days old) and Group 4 (infected at 30 days old). Significant values at $\mathrm{p} \leq$ 0.05 . 


\section{Scoring system}

Scoring system for the renal lesions of NDVinfected-tissues was done according to Hussein et al. (2018) with some modification. Briefly, it was as follows: $0=$ no changes; $1=$ few inflammatory cells infiltration in interstitial tissue; 2 = inflammatory cells infiltration and focal degeneration in renal tubules; 3 = inflammatory cells together with foci of necrobiotic changes in renal tubular epithelium and/or glomeruopathy; $4=$ inflammatory cells, necrobiotic changes of the medullary epithelium and renal glomeruopathy.

\section{Statistical analysis}

Statistical analyses were performed using one-way factorial analysis of variance (ANOVA). Statistical significance was defined as $(\mathrm{p} \leq 0.05)$ using SPSS 17.

\section{RESULTS}

\section{Serum biochemical profile}

The mean values of serum uric acid and creatinine were summarized in table 2 and figures 1 and 2. The mean values of serum uric acid was significantly $(p \leq 0.05)$ increased in the infected groups of 20 and 30 day old chicks at 1, 3, 5 and 7 dpi compared with the control noninfected group as well as infected group at 10 days old (figure 1). The mean values of serum creatinine were significantly increased $(p \leq 0.05)$ with advancing age at 1 and 3 dpi with no significant difference between the infected groups of 10 and 20-days old and the highest significant levels were detected in chickens of the 30-day old group at 1 and 3 dpi. The serum creatinine level was significantly increased at 5 and $7 \mathrm{dpi}$ in all infected groups and the values significantly increased with advancing age (figure 2).

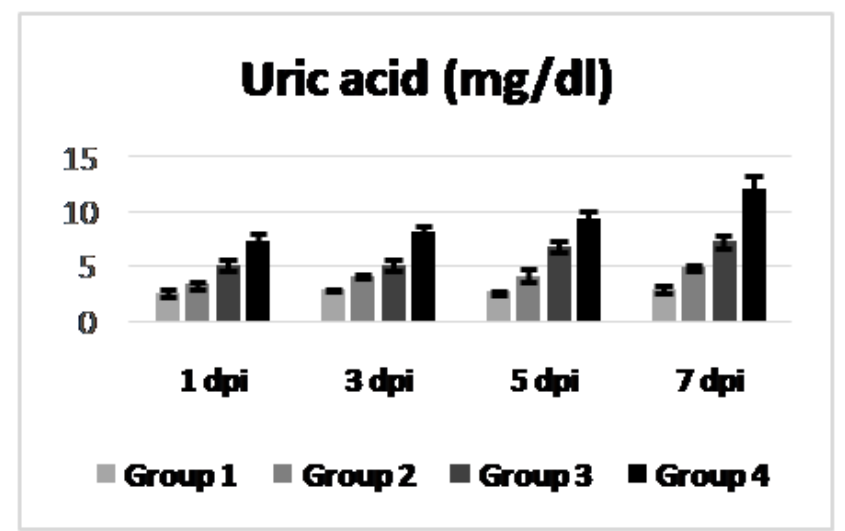

Figure 1. Serum uric acid profile of control and infected broiler chickens at $1,3,5$ and $7 \mathrm{dpi}$

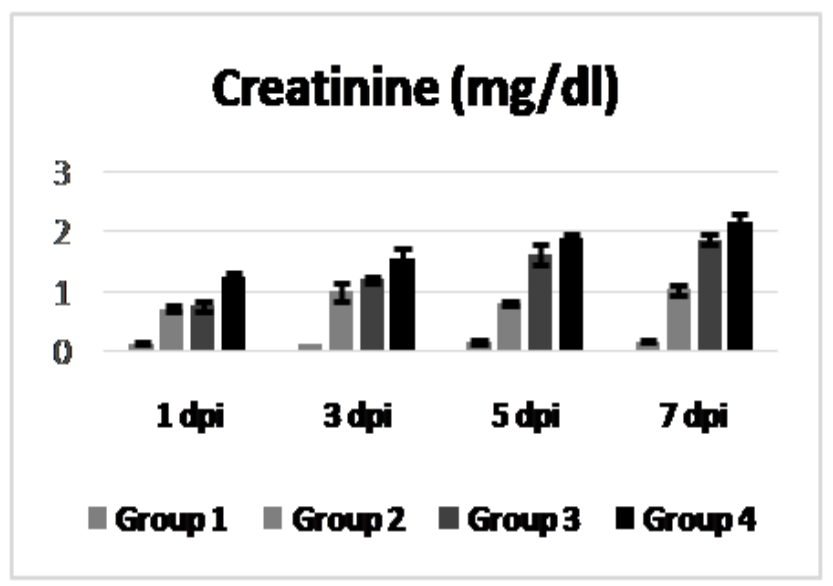

Figure 2. Serum creatinine profile of control and infected broiler chickens at 1,3,5 and $7 \mathrm{dpi}$

\section{Real-Time PCR and cytokine mRNA gene expression}

The PCR result confirmed the highest detection for VND in kidneys' tissues collected at 7 dpi was in group 4 . (30 days-old) in comparison with groups 2 and 3 (10 and 20 days-old). The gene expression of IL6 was significantly increased in Group 4 compared with groups 2 and 3. Meanwhile, no significant difference in gene expression of IFN- $\gamma$ was detected in the infected 10-20-day-old chickens compared with the 30-day old group that conversely showed a significant higher expression of IFN- $\gamma$ (figure 3).

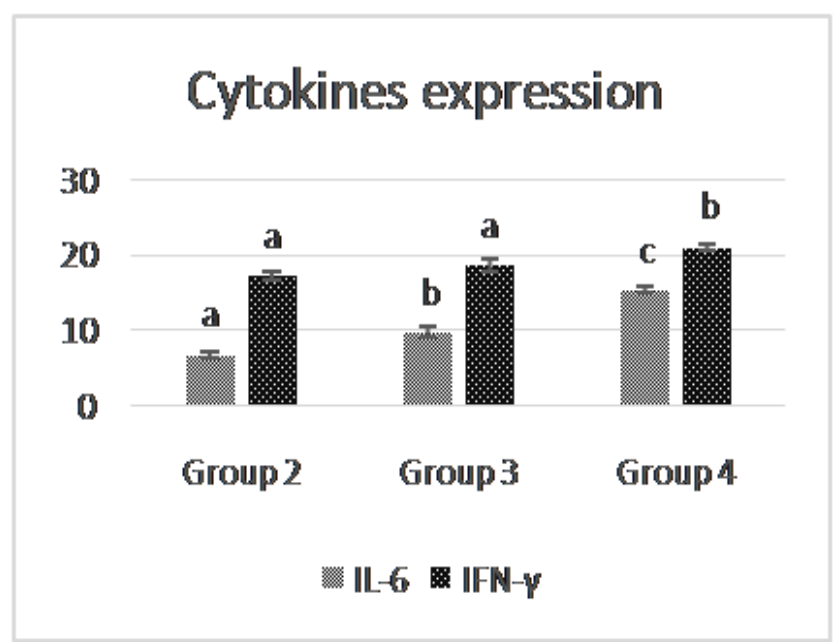

Figure 3. Relative expression of cytokines in the kidneys of infected broiler chickens from different infected groups at $7 \mathrm{dpi}$ for IL-6 and IFN- $\gamma$. Error bars represent the standard error of the mean $(n=3)$. Significant values at $\mathrm{p}$ $\leq 0.05$. a, b and $\mathrm{c}$ above the error bar indicate a significant different between values within the same data series. 


\section{Histopathology and histochemistry}

Group 1 showed normal histological structure in all sacrifices which present cortical areas composed of closely packed nephrons and medullary cones (medullary tracts) containing collecting tubules, looped tubules of the mammalian nephrons, ureteral branches and a network of blood capillaries in interstitial connective tissue. At $1 \mathrm{dpi}$ all infected groups presented vascular changes characterized by perivascular oedema and haemorrhage with congestion of peritubular capillary sinuses. Group 2 and group 3 showed at 1 and 3 dpi mild to moderate necrobiotic changes. Meanwhile, Group 4 showed moderate necrobiotic changes admixed to focal interstitial nephritis at 1 dpi characterized by mononuclear and heterophilic cells infiltration (figure 4a).

At $5 \mathrm{dpi}$, the inflammatory reaction was evident in all the infected groups with variable severity. Group 2 showed focal pattern of interstitial nephritis, while groups 3 and 4 exhibited multifocal to diffuse interstitial nephritis (figure 4b) mixed with glomerular changes. At $7 \mathrm{dpi}$, group 2 showed mild histoapthological alterations in which renal tubular epithelium showed necrosis with focal interstitial nephritis (figure 4c). Severe necrosis of tubular epithelium developed in groups 3 and 4 mixed with diffuse cortical interstitial nephritis (figure $4 \mathrm{~d}$ and e). Moreover, some examined sections from group 4 tended to show more severe lesions by extending the inflammatory reaction into the medullary cones (figure $4 \mathrm{f}$ ) with mild cortical interstitial fibrosis.

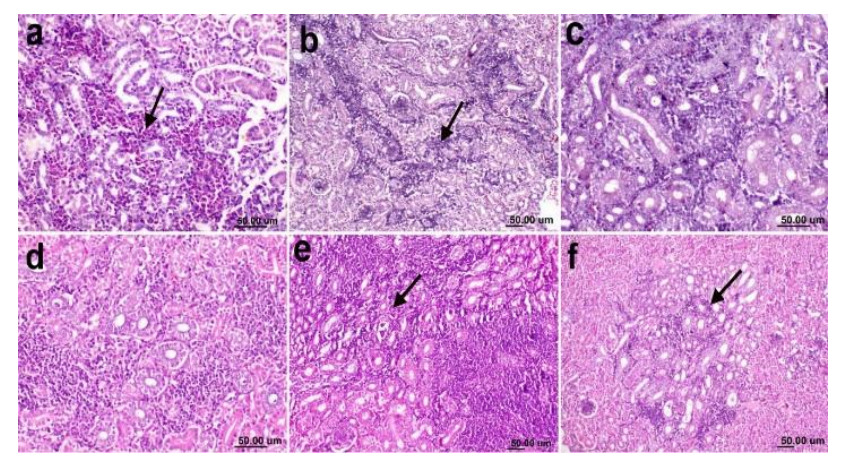

Figure 4. Histological kidney sections stained by $\mathrm{H}$ \& $\mathrm{E}$ from infected broiler chickens. a: Group 4 at 1 dpi showing heterophilic interstitial nephritis (arrow). b: Group 3 at 5 dpi showing multifocal mononuclear cell aggregation (arrow). (c) Group 2 at 7 dpi showing mild mononuclear cells infiltration. d: Group 3 at 7 dpi showing diffuse mononuclear cells infiltration. e: Group 4 at 7 dpi showing diffuse mononuclear cells infiltration the renal cortex and necrosis of renal tubular epithelium (arrow). f: Group 4 at 7 dpi showing diffuse mononuclear cells infiltration in the medullary cone (arrow).
At 7 dpi, kidneys from group 2 exhibited membranous glomerulopathy affecting few glomeruli. The lesion was characterized by thickening of glomeular basement membrane (figure 5a), whereas group 3 at 5 and 7 dpi presented moderate number of glomerular changes characterized by membranous and proliferative glomerulopathy manifested by large sized glomeruli and hypercellularity due to the increase in the mesangial cells (figure 5b). Moving to group 4, glomerular changes started earlier at 3 dpi with membranous glomerulopathy, and many glomeruli showed proliferative glomerulopathy at 5 dpi (figure 5c). Moreover, atrophy of glomerular capillary tuft (figure 5d) was observed in some glomeruli in group 4 at $7 \mathrm{dpi}$, whereas other glomeruli showed membranous glomerulopathy with mononuclear cells infiltration in the interstitial tissue (figure 5e).

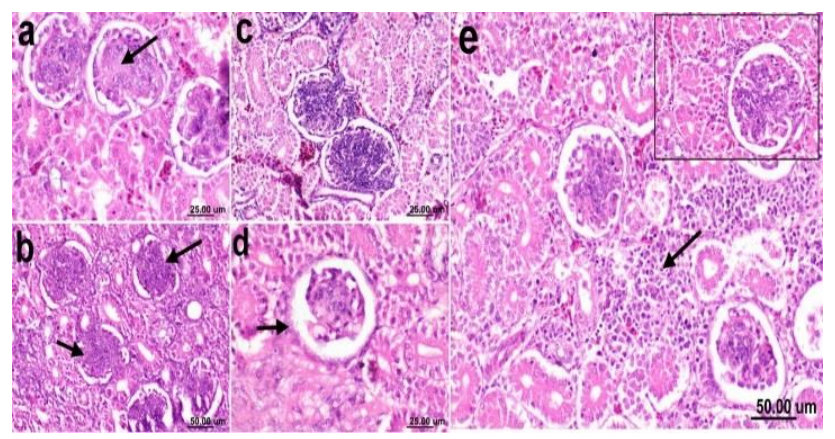

Figure 5. Histological kidney sections stained by $\mathrm{H} \& \mathrm{E}$ from infected broiler chickens. a: Group 2 at $7 \mathrm{dpi}$ showing membranous glomerulopathy with thickening of glomerular basement membrane (arrow). b: Group 3 at 7 dpi showing proliferativglomerulopathy characterized by enlarged glomeruli with glomerular hypercellularity (arrow). c: Group 4 at 5 dpi showing proliferative glomerulopathy that showed both glomerular hypercellurity and thickening of glomerular basement membrane. d: Group 4 at $7 \mathrm{dpi}$ showing atrophy of glomerular capillary.

The mild peritubular and interstitial fibrosis were detected in group 4 and was confirmed by MTC stain (figure 6a) by which the periglomerular deposition of delicate collagen fibers was noticed (figure $6 b$ and c). Thickening of the glomerular capillary wall in different infected groups was positively stained by PAS stain. Also, the renal tubules showed destruction and loss of continuation of the apical brush border of the proximal convoluted tubules with decreased PAS staining affinity of apical borders of tubular epithelium (figure $6 \mathrm{~d}$ and e). 


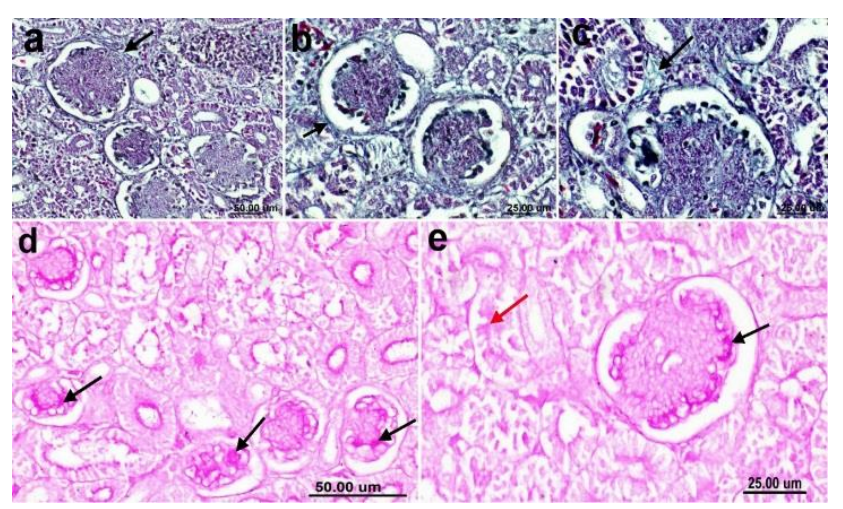

Figure 6. Masson's Trichrom stained sections of infected broiler chickens from group 4 at 7 dpi. a: peritubular and interstitial fibrosis (arrow). b and c: showing periglomerular deposition of delicate collagen bundles (arrow). d: Periodic acid-Schiff stained sections of chicken from group 2 at $7 \mathrm{dpi}$ highlighting the thickening of the glomerular capillary walls (arrows). e: PAS stained section from group 4 at 7 dpi illustrating the thickening of the glomerular capillary tuft (black arrow) with loss of continuation of the apical brush border of the proximal convoluted tubules (red arrow).

\section{Immunohistochemistry}

Group 1 showed negative peroxidase reaction for NDV antigen (figure $7 \mathrm{a}$ ). At $7 \mathrm{dpi}$, expression of viral antigen was detected in several areas of the renal tissue; renal tubular epithelium $\mathrm{d}$ showed strong positive reaction of NDV antigen especially in the degenerated tubular epithelium (figure 7b). Medullary cone showed positive IHC reaction for NDV (figure 7c). Glomeruli of different infected groups exhibited positive expression of viral antigen in the capillary tuft (figures $7 d$ and $7 e$ ). Some major ureter branches showed positive expression of the viral antigen in pseudostratified columnar epithelial lining (figure 7f).

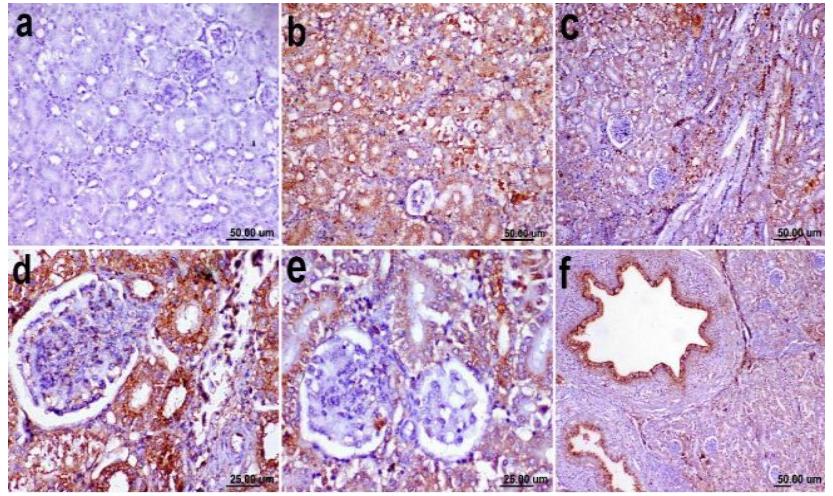

Figure 7. Immunohistochemical reaction of broiler chickens from different experimental groups at $7 \mathrm{dpi}$; $\mathbf{a}$ : Group 1 showed negative peroxidase reaction for NDV. b: Positive expression of the viral antigen lining epithelium of the degenerated tubules. c: Viral expression was detected in the medullary cones of the infected birds. d and e: Positive IHC for NDV was detected in the glomerular capillary tuft. f: Major ureter branches showed positive expression of the NDV in pseudostratified columnar epithelial lining.

\section{Histopathological lesions score}

The results of histopathological lesion score are summarized in table 3. All infected groups showed increased lesion severity $(p \leq 0.05)$ in all infected sacrifices when compared to group 1 (control group) which exhibited normal histological structure. Group 4 showed the highest lesions scoring in all sacrifices compared to other infected groups and a significant difference between it and the other infected groups (Groups 2 and 3) at 1 and 5 dpi recording 1.73 and 2.4, respectively. At $7 \mathrm{dpi}$, the highest lesion scores were observed in all infected groups and no significant difference ( $\mathrm{p} \leq 0.05$ ) was detected between group 3 and group 4 which scored 2.66 and 2.73 , respectively (table 3 ).

Table 3. Histopathological lesions score induced by NDV in the renal tissues of broiler chickens from different experimental groups at $1,3,5$ and $7 \mathrm{dpi}$

\begin{tabular}{ccccc}
\hline Groups & 1dpi & 3dpi & 5dpi & 7dpi \\
\hline Group 1 & $00.00 \pm 0.00$ & $00.00 \pm 0.00$ & $00.00 \pm 0.00$ & $00.00 \pm 0.00$ \\
Group 2 & $1.00 \pm 0.29^{\mathbf{a}}$ & $1.00 \pm 0.13^{\mathbf{a}}$ & $1.60 \pm 0.19^{\mathbf{a}}$ & $2.06 \pm 0.66^{\mathbf{a}}$ \\
Group 3 & $1.06 \pm 0.20^{\mathbf{a}}$ & $1.46 \pm 0.16^{\mathbf{b}}$ & $1.86 \pm 0.27^{\mathbf{a}}$ & $2.66 \pm 0.33^{\mathbf{b}}$ \\
Group 4 & $1.73 \pm 0.20^{\mathbf{b}}$ & $1.80 \pm 0.17^{\mathbf{b}}$ & $2.40 \pm 0.16^{\mathbf{b}}$ & $2.73 \pm 0.00^{\mathbf{b}}$ \\
\hline
\end{tabular}

Values expressed as means \pm Standard Error

\section{DISCUSSION}

As for NDV affecting broilers in developed and developing countries, massive economic losses occurred due to outbreaks in many localities (Cattoli et al., 2011).
Until now, it has not been clear whether there is a specific host-cell protease responsible for cleavage of the different F0 proteins. Briefly, there is a correlation between virulence or pathogenicity and a high content of basic amino acid residues at the F0 cleavage site (De Leeuw et 
al., 2003) which allows systemic distribution of virulent strains of NDV.

Serum uric acid and creatinine levels are used mainly as markers of renal functions and indicators to different histopathological alterations of kidney (Sanders et al., 1980). Serum uric acid level is the primary marker of renal functions in avian species (Tully et al., 2009). Increased serum levels of these parameters in the infected groups occurred due to severe kidney pathology that was detected in all infected groups. In addition, there was a correlation between increased serum level and the severity of renal pathology). (table 2 and figures 1, 2, $4 \& 5$ ). These results confirmed that the developed nephropathy induced by NDV severely affects the kidney functions as confirmed by Najafi et al. (2014). Renal tubules necrobiotic changes may lead to hyperuricemia, as Okorie-Kanu et al. (2016) stated that over $80 \%$ of nitrogen excreted by birds are in the form of uric acid through tubular secretion. Meanwhile, Echols et al. (2006) mentioned that blood uric acid levels are mildly affected by the birds' hydration status, but they reflect the functional capacity of the renal proximal tubules. Loss of renal function combined with water deprivation during the peak of clinical signs may enhance the effect (El-Bahrawy et al., 2017).

IL-6 is a pro-inflammatory cytokine involved in acute-phase responses, immune regulation and hematopoiesis (Hirano, 1998). IL-6 plays a role in the activation of $\mathrm{B}$ and $\mathrm{T}$ lymphocytes, induction of macrophage production and development. Moreover, it acts synergistically with granulocyte-macrophage colony stimulating factor (GMCSF) (Wigley and Kaiser, 2003).

Using real-time RT-PCR of RNA isolated from NDV-infected kidneys, we demonstrated that the virulence of NDV was increased in the older age indicating the increased rate of viral dissemination and replication in kidney tissue with advancing age. Thus, it interpreted the age related increase in inflammatory cytokines in renal tissue with subsequent severe nephropathy and inflammatory reaction that were detected in older ages of infected chickens. This result was agree with Rue et al. (2011) who mentioned that virulent strain of NDV is capable of rapid and strong releasing of IFN- $\gamma$ and IL-6. Moreover, Alexopoulou et al. (2001) characterized IL-6 as an early innate response due to viruses. Furthermore, IFN- $\gamma$ activate macrophage and modulat the immune system (De Mayer and De Mayer-Guinard, 1998).

In our results, we early observe heterophils in renal intersitium in all infected groups. This explained by Anis et al. (2012) who stated that avian heterophils are highly phagocytic and capable of a broad spectrum of antimicrobial activity, and they form the first line of cellular defense against invading pathogens. Additionally, in the present results, severe lesions occurred in kidney observed at a late phase of infection ( 5 and $7 \mathrm{dpi}$ ), and these were in agreement with previous report by Wen et al. (2016) who mentioned that nephritis developed as the virus invaded respiratory tract, replicated inside mucosal epithelial cell of the upper respiratory tract and digestive tract and then, right after infection, the virus spread through blood circulation to kidney. Lately, it has been observed that severe interstitial nephritis observed in our study was similar to Anis et al. (2012) who detected tubulointerstitial nephritis by the sixth dpi with associated NDV-NP-immunopositive staining in the degenerated renal tubules. The severe damage occurring in the kidney may be attributed to the direct effect of the viral replication in the renal tubular epithelial, which was confirmed by expression of the viral antigen in degenerated tubular epithelium by immunohistochemistry and confirmed by the increased gene expression of inflammatory cytokines in kidneys of infected chickens. Moreover, Vascular changes that occurred in the present study may be due to the adjacent focal inflammation as vessels adjacent to primary areas of infection can show some degrees of hyaline degeneration, which most likely due to intense exudation of proteins (Cattoli et al., 2011).

The distribution of renal lesion in the present study was different depending on the age of infected chickens with increased distribution of renal glomerular, tubular and interstitial pathology with advancing age to involve both cortex and medullary cones. The susceptibility of the renal cortex and the medulla to NDV infection in birds are unknown as the $\mathrm{pH}$ is variable (Echols, 2006). Furthermore, species also varied in the susceptibility of renal infection. Anis et al. (2012) concluded that, in a comparison study between chickens and ducks, Tubulointerstitial nephritis was noticed only in chickens and the lesions dramatically developed at the late stage and did not subside until the $10^{\text {th }} \mathrm{dpi}$. In addition to the previously mentioned factors, age appeared to affect susceptibility to infection as older birds in our study showed more severe lesions compared with younger birds. This was confirmed by a previous related study on the age factor affecting severity of infection in immune organs. This result was in agreement with Mohammed et al. (2019) and Mousa et al. (2019) who concluded that the older chickens are more susceptible to infection with more developed histopathological alteration and more expression of viral antigen in the exposed tissues. 
The glomerular changes, including membranoproliferative lesions, occurred in association with viral disease that proposes an immune complexmediated form of glomerulonephritis as we detected NDV antigen in glomerular tuft by immunohistochemistry. Membranoproliferative glomerular lesions were seen with neoplasia, autoimmune disorders, and persistent infections or other diseases producing prolonged antigenic stimulation including viral and bacterial infections (Maxie and Prescott, 1993; Wilson et al., 2010). Maxie and Prescott (1993) added that the glomeruli variably respond to the damage by cellular proliferation or thickening of the basement membrane.

In our study, viral antigen was expressed in several areas of infected kidneys, similar results obtained by ElBahrawy et al. (2017) who stated that most immunostaining for NDV- NP was distributed in a multifocal pattern in the intact and vacuolated epithelium of proximal and distal tubules, in infiltrating macrophages, in some cells of reptilian-type glomeruli in the cortex, and in medullary cones mainly in the tubular epithelium and the infiltrating mononuclear cells. Moreover, Susta et al. (2011) stated that several epithelial cells in the distal tubules of the kidneys had positive signal for ND.

\section{CONCLUSION}

The present study showed an age-related difference in Newcastle disease virus replication and dissemination into renal tissue. Such difference is correlated with gene expression of inflammatory cytokines with subsequent increase of the severity of nephropathy with advancing age that dramatically affects renal function and reflects the health status of broiler chickens. These results highlight the importance of NDV as one of the diseases that could contribute to kidney affection in broiler chickens under field condition. Glomerulopathy developed in the infected birds showed a new feature of NDV which was increased with age.

\section{DCLARATIONS}

\section{Acknowledgments}

The authors would like to acknowledge Dr. Hanan S Khalefah, department of Veterinary Hygiene and Management, Faculty of Veterinary Medicine, Cairo University.

\section{Competing interests} interests.
Ethical approval

This experimental protocol was approved by Institutional Animal Care and Use Committee (IACUC), Cairo University, Egypt (Approval number, $\mathrm{CU} / \mathrm{II} / \mathrm{F} / 65 / 17)$.

\section{Authors' contributions}

Mohamed R. Mousa, Faten F. Mohammed, Kawkab A. Ahmed: Data collection and study design planning. Histopathological, histochemical and immunehistochemical analysis. Fatma Amer Abdel reheem: RealTime PCR and cytokine mRNA gene expression. Ayman H. El-deeb: study design planning and virus infectivity titration. All authors: Data interpretation, final manuscript writing, editing and revising.

\section{REFERENCES}

Alexopoulou L, Holt AC, Medzhitov R and Flavell RA (2001). Recognition of double-stranded RNA and activation of NF-kappaB by Toll-like receptor 3. Nature, 413: 732. DOI: https://www.nature.com/articles/35099560.

Anis Z, Morita T, Azuma K, Ito H, Ito T and Shimada A (2012). Comparative Study on the Pathogenesis of the Generated 9a5b Newcastle Disease Virus Mutant Isolate Between Chickens and Waterfowl. Veterinary Pathology, 50: 638-647. DOI: https://doi.org/10.1177/0300985812467470.

Bancroft JD (2013). Histochemical techniques. Butterworth-Heinemann. Available at: https://www.elsevier.com/books/histochemicaltechniques/bancroft/978-0-407-00033-9.

Bowers LD and Wong ET (1980) Kinetic serum creatinine assays. II. A critical evaluation and review. Clinical chemistry, 26: 555-561. DOI: https://www.ncbi.nlm.nih.gov/pubmed/7020989.

Burns Robert (2005). Immunochemical protocols. Vol. 295. Totowa, NJ: Humana Press. Available at https://www.springer.com/gp/book/9781588292742.

Cattoli G, Susta L, Terregino C and Brown C (2011). Newcastle disease a review of field recognition and current methods of laboratory detection. Journal of Veterinary Diagnostic Investigation, 23: 637656. DOI: https://doi.org/10.1177/1040638711407887.

Council NR (1971). Methods for Examining Poultry Biologics and for Identifying and Quantifying Avian Pathogens: Report of the Subcommittee on Avian Diseases, Committee on Animal Health, Agricultural Board, National Research Council. National Academy of Sciences. Available at: https://ucdavis.on.worldcat.org/discovery

De Mayer EM and De Mayer-Guinard J (1998). Interferons. In: AW Thomson (editor). The Cytokine Handbook 3rd edition. Academic Press, San Diego, 491-515.

Echols MS (2006). Evaluating and Treating the kidneys. Clinical Avian Medicine, 2: 451-492.

El-Bahrawy A, Zaid A, Sunden Y, Sakurai M, Ito H, Ito T and Morita T (2017). Pathogenesis of Renal Lesions in Chickens After Experimental Infection With 9a5b Newcastle Disease Virus Mutant Isolate. Veterinary Pathology, 54: 94-98. DOI: https://doi.org/10.1177/0300985816655852.

Hirano T (1998). Interleukin 6. In: AE Thomson (editor). The Cytokine Handbook 3rd edition. Academic Press, San Diego, 197-227. Available at: http://www.med.osaka u.ac.jp/pub/molonc/www/old/Eindex.html.

Hussein EA, Hair-Bejo M, Adamu L, Omar AR, Arshad SS, Elmutaz AA and Aini I (2018). Scoring System for Lesions Induced by Different Strains of Newcastle Disease Virus in Chicken. 
Veterinary Medicine International, 1-9. DOI: https://doi.org/10.1155/2018/9296520.

Kaiser P, Rothwell L, Galyov EE, Barrow PA, Burnside J and Wigley P (2000). Differential cytokine expression in avian cells in response to invasion by Salmonella typhimurium, Salmonella enteritidis and Salmonella gallinarum. Microbiology, 146: 3217-3226. DOI: https://doi.org/10.1099/00221287-146-12-3217.

de Leeuw OS, Hartog L, Koch G and Peeters BPH (2003). Effect of fusion protein cleavage site mutations on virulence of Newcastle disease virus: Non-virulent cleavage site mutants revert to virulence after one passage in chicken brain. Journal of General Virology, 84: 475-484. DOI: https://doi.org/10.1099/vir.0.18714-0.

Livak KJ and Schmittgen TD (2001). Analysis of relative gene expression data using real-time quantitative PCR and the 2- $\Delta \Delta \mathrm{CT}$ method. Methods, 25: 402-408. DOI: https://doi.org/10.1006/meth.2001.1262.

Maxie MG and Prescott JF (1993). The urinary system. In: Pathology of domestic animals. K. V. F. Jubb, P. C. Kennedy, and N. Palmer, eds. Academic Press, New York, 2: 478-481. available at: https://www.elsevier.com/books/jubb-kennedy-and-palmerspathology-of-domestic-animals-volume-3/9780702053191.

Mohammed FF, Mousa MR, Khalefa HS, El-Deeb AH and Ahmed KA (2019). New insights on neuropathological lesions progression with special emphasis on residence of velogenic Newcastle disease viral antigen in the nervous system of experimentally infected broiler chickens. Exploratory Animal and Medical Research, 9(2): 145157. Avaliable at: www.animalmedicalresearch.org.

Mousa MR, Mohammed FF, Khalefah HS, El-deeb AH and Ahmed KA (2019). Comparative Serological, Histopathological and Immunohistochemical Evaluation of Immune Status of Broiler Chickens Experimentally Infected with Velogenic Newcastle Disease Virus in Different Ages. International Journal of Veterinary Science, 8: 143-150. Available at :www.ijvets.com

Nagai Y (1993). Protease-dependent virus tropism and pathogenicity. Trends in Microbiology, 1: 81-87. DOI: https://doi.org/10.1016/0966-842X(93)90112-5.

Najafi H, Ghalyanchi-Langeroudi A, Hashemzadeh M, Madadgar O and Karimi V (2014). Comparison of Laboratory Parameters in the Serum of SPF Chickens Infected with Different Iranian Genotypes of Infectious Bronchitis Virus. Iranian Journal of Virology, 8: 1-6. Avialable at: http://journal.isv.org.ir/article-1-163-en.html.

Okorie-Kanu CO, Okorie-Kanu OJ, and Okoye JOA (2016). Blood biochemistry responses of ducks infected with a velogenic Newcastle disease virus. Comparative Clinical Pathology. Comparative Clinical Pathology, 25: 681-688. Avialable at: https://link.springer.com/article/10.1007/s00580-013-1870-x.

Piacenti A M, King DJ, Seal BS, Zhang J and Brown CC (2006). Pathogenesis of Newcastle disease in commercial and specific pathogen-free turkeys experimentally infected with isolates of different virulence. Veterinary pathology, 43: 168-78. DOI: https://doi.org/10.1354/vp.43-2-168
Reed LJ and Muench H (1938). A simple method of estimating fifty per cent endpoints. American journal of epidemiology, 27: 493-497. DOI: https://doi.org/10.1093/oxfordjournals.aje.a118408

Rue CA, Susta L, Cornax I, Brown CC, Kapczynski DR, Suarez DL, King DJ, Miller PJ and Afonso CL (2011). Virulent Newcastle disease virus elicits a strong innate immune response in chickens. Journal of General Virology, 92: 931-939. DOI: https://doi.org/10.1099/vir.0.025486-0

Samiullah M, Rizvi F, Anjum AD and Shah MFA (2006). Rising hyperimmune serum against avian paramyxovirus (APMV-1) and pigeon paramyxovirus (PPMV-1) in rabbits and their crossreactivity. Pakistan Journal of Biological Sciences, 9: 2184-2186. DOI: 10.3923/pjbs.2006.2184.2186

Sanders GTB, Pasman AJ and Hoek FJ (1980). Determination of uric acid with uricase and peroxidase. Clinica Chimica Acta, 101: 299303. DOI: https://doi.org/10.1016/0009-8981(80)90257-0

Sultan HA, Shaimaa T, Wael Kl, Karim SZ, Mohamed AK, Sameh AA and Kang SC (2020). Protective efficacy of the Newcastle disease virus genotype VII-matched vaccine in commercial layers. Poultry Science, 99:1275-1286. https://doi.org/10.1016/j.psj.2019.10.063.

Susta L, Miller PJ, Afonso CL and Brown CC (2011). Clinicopathological characterization in poultry of three strains of Newcastle disease virus isolated from recent outbreaks. Veterinary pathology, 48: 349-360. https://doi.org/10.1177/0300985810375806

Tiffany TO, Jansen JM, Burtis CA, Overton JB and Scott CD (1972). Enzymatic kinetic rate and end-point analyses of substrate, by use of a GeMSAEC fast analyzer. Clinical Chemistry, 18: 829-840. DOI: https://doi.org/10.1093/clinchem/18.8.829

Tully TN, Dorrestein GM and Jones AK (2009). Handbook of avian medicine. https://www.elsevier.com/books/handbook-of-avianmedicine/9780702028748

Wen G, Hu X, Zhao K, Wang H and Zhang Z (2016). Molecular basis for the thermostability of Newcastle disease virus. Scientific Reports, 6: 1-9. DOI: https://www.nature.com/articles/srep22492

Wigley P and Kaiser P (2003). Avian cytokines in health and disease. Brazilian Journal of Poultry Science, 5: 1-14. DOI: https://doi.org/10.1590/S1516-635X2003000100001

Wilson FD, Wills RW, Senties-Cue CG, Maslin WR, Stayer PA and Magee D (2010). High Incidence of Glomerulonephritis Associated with Inclusion Body Hepatitis in Broiler Chickens: Routine Histopathology and Histomorphometric Studies. Avian Diseases, 54: 975-980. DOI: https://doi.org/10.1637/9050-090709-Reg.1

Wise MG, Suarez DL, Seal BS, Pedersen JC, Senne DA, King DJ, Kapczynski DR and Spackman E (2004). Development of a realtime reverse-transcription PCR for detection of Newcastle disease virus RNA in clinical samples. Journal of Clinical Microbiology, 42: 329-338. DOI: https://jcm.asm.org/content/42/1/329 